індивідуалізації процесу підготовки особистості до професійної діяльності на основі створення структури мистецько-освітнього процесу 3 урахуванням зовнішніх, внутрішніх і змішаних рівнів взаємозв'язків мистецтва, культурно-мистецької, професійно-мистецької, художньотворчої і мистецько-педагогічної практики у процесі багаторівневої інтеграції компонентів системи освітнього і соціокультурного простору сучасності. У зв'язку з вище викладеним виникає потреба розглядати процес професійної підготовки фахівців мистецьких спеціальностей як поліінтегровану багаторівневу систему, компоненти якої повинні динамічно розпредмечувати внутрішній культурологічний зміст структури особистості, враховуючи різноманітні можливості застосування професійного досвіду сучасного митця в суспільстві.

Перспективи подальшого дослідження становлять визначення методології багаторівневої мистецько-освітньої інтеграції та стратегій подальшого розвитку системи підготовки фахівців мистецьких спеціальностей у вищих навчальних закладах України.

\title{
Література
}

1. Большая советская энциклопедия (в 30 томах) / гл. ред А. М. Прохоров. - [Изд. 3-е.]. - М.: Советская энциклопедия, 1972. - Т. 10. - Ива-Италики, 1972. - 592 с., с илл. 2. Великий тлумачний словник сучасної української мови / уклад. і голов. ред. В. Т. Бусел. - К. : Ірпінь: ВТФ «Перун», 2007. 1736 с.: іл. 3. Кондаков Н. И. Логический словарь-справочник / Н. И. Кондаков. - М.: Наука, 1975. 720 с. 4. Кононенко Б. И. Большой толковый словарь по культурологии / Б. И. Кононенко. - М.: ООО «Издательство «Вече 2000», ООО «Издательство АСТ», 2003. - 512 с. 5. Пономарьова О. М. Деякі аспекти художньої інтеграції мистецтв у формуванні музично-естетичних орієнтацій майбутніх учителів / О. М. Пономарьова. - Педагогічні науки: [зб. наук. праць]. - Херсон: Вид-во ХДУ, 2005. Вип. 39. - С. 313-315. 6. Рудницька О. П. Педагогіка: загальна та мистецька / Оксана Петрівна Рудницька. - К., 2002. - 270 с. 7. Падалка Г. М. Педагогіка мистецтва (Теорія і методика викладання мистецьких дисциплін) / Г.М. Падалка. - К. : Освіта Україна, 2008. - 274 с. 8. Философский энциклопедический словарь / редкол. С. С. Аверинцев, Э. А. Араб-Оглы, Л. Ф. Ильичев и др. - [2-е изд.]. - М.: Сов. энциклопедия, 1989. - 815 с.

УДК 316.346.2:316.356.2.37.011.3

Ганна Приходько

\section{РОЛЬ ГЕНДЕРНИХ СТЕРЕОТИПІВ У КОНТЕКСТІ ДОСЛІДЖЕННЯ ПРОБЛЕМ СІМЕЙНОГО ВИХОВАННЯ}

Приходько Г. В. Роль гендерних стереотипів у контексті дослідження проблем сімейного виховання.

У статті розглянуто роль гендерних стереотипів у контексті теорії соціального конструювання статі. 3'ясовано, що такі стереотипи зумовлюють зміст, принципи та методи сімейного виховання, визначають ступінь залучення батьків до вихованнчя та особливості ставлення загалом до дітей залежно від їхньої статі.

Ключові слова: гендер (соціальна стать), біологічна стать, гендерний підхід, гендерні стереотипи, сімейне виховання.

Приходько А. В. Роль гендерных стереотипов в контексте исследования проблем семейного воспитания.

Статья посвящена раскрытию роли гендерных стереотипов в контексте теории социального конструирования пола. Выяснено, что такие стереотипы определяют содержание, принципы и методы семейного воспитания, степень участия родителей в воспитании, их отношение в целом к детям в зависимости от их пола.

Ключевые слова: гендер (социальный пол), биологический пол, гендерный подход, гендерные стереотипы, семейное воспитание.

Prihodko A. V. The gender stereotypes role in the context of family education problems.

The article is devoted to the role of gender stereotypes. According to the text gender stereotypes are influences over the contents, principles and methods of the family education; determines the degree of parents' participation in this process and there relations with boys and girls.

Key words: gender, sex, gender approach, gender stereotypes, social-cultural nature, family education. 
Важливим етапом розвитку і формування особистості дітей обох статей є період сімейного виховання, коли хлопчики і дівчата отримують перший досвід взаємодії й спілкування, починають активно засвоювати і відтворювати моделі поведінки, соціальні ролі. Маємо підстави стверджувати, що, попри декларування Українською державою пріоритету розвитку кожної особистості як суб'єкта діяльності, у сімейному колі подекуди продовжують транслюватися традиційні уявлення щодо призначення й моделей поведінки чоловіка та жінки, які нівелюють індивідуальні здібності й таланти дитини. За рахунок існування гендерних стереотипів на рівні культури здійснюється утвердження ідеології патріархату в багатьох сучасних родинах, згідно з якою соціальне виправдання отримують відмінності за ознакою статі, гегемонія маскулінності й стратифікація між дітьми протилежної статі.

Під гендерними стереотипами сучасні дослідники (І. Кльоцина, Н. Лавріненко та ін.) розуміють стандартизовані уявлення про моделі поведінки й риси характеру, які відповідають поняттю «чоловіче» й «жіноче» [8, с. 19]. У науковому дискурсі розробленими $\epsilon$ питання природи, причин виникнення й механізмів включення гендерних стереотипів у соціальний простір. Зарубіжними і вітчизняними дослідниками (О. Вілкова, Т. Власова, О. Вороніна, К. Джеклін, Т. Дороніна, І. Жеребкіна, О. Здравомислова, І. Кльоцина, В. Кравець, Н. Кутова, Е. Маккобі, С. Оксамитна, А. Темкіна та ін.) стереотипи маскулінності й фемінності розглядаються передусім як універсальні механізми відтворення традиційних гендерних відносин у різних сферах життєдіяльності людства.

Сім'я як осередок формування гендерних відносин і відтворення гендерних стереотипів $\epsilon$ предметом активних досліджень Т. Гурко, О. Кісь, Н. Лавріненко, М. Малишевої, Н. Пушкарьової, Т. Рябової, Н. Усачевої та ін.

Однак, вивчення проблем сімейного виховання крізь призму функціонування таких стереотипів науковцями проводиться, на наш погляд, недостатньо. Зазвичай дослідники констатують факт неоднакової участі батька й матері у виховному процесі та засвоєння дітьми гендерних стереотипів, не вдаючись до розкриття каузальності процесу.

Такий стан розроблення проблеми та ії актуальність зумовлюють мету статті, яка полягає у з'ясуванні особливостей функціонування гендерних стереотипів на рівні компонентів сімейного виховання. Це видається доцільним з огляду на нагальну потребу утвердження культури стосунків між статями в сучасних українських родинах, що відповідає загальним тенденціям інтеграції українського суспільства до європейської спільноти.

Провідні теоретики сімейного виховання (Т. Алексеєнко, В. Бондаровська, І. Гребенников, М. Тадеєва, В. Федяєва та ін.) визначають його як форму виховання дітей, що поєднує цілеспрямовані, усвідомлені та бажані дії батьків із повсякденним впливом сімейного побуту; підготовку дітей до життя в існуючих соціальних умовах, набуття ними знань, умінь і навичок, необхідних для повноцінного формування особистості в умовах соціуму.

Спираючись на сучасну педагогічну теорію, уважаємо, що сімейне виховання доцільно та більш ефективно вивчати як систему, яка вміщує такі взаємопов'язані компоненти: 1) вплив батьків (або осіб, що їх замінюють) на особистість дітей; 2) розвиток особистості самих дітей; 3) власне процес сімейного виховання - мету, зміст, принципи, методи і засоби виховання; 4) критерії ефективності сімейного виховання.

У цій статті спробуємо розкрити механізми творення й дії гендерних стереотипів на рівні перших трьох визначених компонентів. Спершу зупинимося на деяких методологічних аспектах вивчення стереотипів маскулінності і фемінності.

За визначенням науковців, стереотипом [гр. stereos твердий + typos відбиток] $\epsilon$ стандартизований, стійкий, емоційно насичений, ціннісно визначений образ або уява про соціальний об'єкт [9, с. 95]. На рубежі XX - XXI ст. теоретичною основою для пояснення стереотипів, за даними Т. Власової, був соціально-когнітивний підхід, відповідно до якого стереотип - це система положень, що певним чином спрямовує засвоєння будь-якої інформації, зокрема й гендерної [4, с. 9].

Однак, стереотипи за ознакою статі, стверджує Н. Кутова, є не просто образами чи то шаблонами, вони спричиняють поділ людства на дві опозиційні групи: чоловічу й жіночу [9, с. 95]. Результатом цього розподілу стало виникнення та укорінення стереотипів «маскулінності» і «фемінності», які грунтуються на ідеї про протиставлення жіночого й чоловічого, різне соціальне призначення людей залежно від їхньої біологічної статі. Чоловікам традиційно 
приписуються такі риси характеру, як раціональність, сила, відважність, самовпевненість тощо, а їхніми соціальними ролями вважаються професійні ролі та предметно-інструментальна сфера діяльності. Натомість жінки стереотипно сприймаються як слухняні, боязкі, залежні, орієнтовані на догляд і турботу, головним їхнім соціальним призначенням є сімейні ролі (матері, дружини, господині) й емоційно-експресивна сфера діяльності [8, с. 19].

Досить змістовну характеристику цих стереотипів подано в роботі Т. Рябової [11], яка, на наш погляд, доповнює відому в наукових колах класифікацію гендерних стереотипів І. Кльоциної.

Таке стереотипне сприймання людей за ознакою їхньої біологічної статі призвело до ієрархічного розподілу між ними економічних і соціальних ресурсів (гендерної стратифікації), розподілу праці на «жіночу» й «чоловічу», нерівнозначного представлення соціальних і культурних ролей чоловіків та жінок у різних галузях суспільного життя (гендерної асиметрії) й, нарешті, утвердження ідеології патріархату - системи ідей про панівне становище чоловіків і підлеглий статус жінок.

Із розвитком проблеми соціальної статі стало можливим вивчення гендерних стереотипів та особливостей їх функціонування в основних сферах життедіяльності суспільства 3 позиції різних методологічних підходів. Основними 3 них $є$ такі: конструктивістський, когнітивна теорія, положення про соціальні ролі, концепція соціальної ідентичності, ідея владних взаємовідносин. Усі теорії належать до різних наукових парадигм, але в полі зору кожної розробка проблем, пов'язаних зі стереотипами мужності та жіночності.

Нині науково обгрунтована доцільність уведення методології соціального конструювання як більш виправданої під час вивчення гендерних стереотипів. Таке методологічне підгрунтя $\epsilon$ опозиційним до есенціалістського підходу та теорії біологічного детермінізму, згідно 3 якими відмінності в соціальних ролях і статусах, психологічних характеристиках жінок і чоловіків виводять з їхніх уроджених (анатомічних, фізіологічних) параметрів.

Теоретико-методологічним підгрунтям конструктивістського уявлення про гендер як соціальну особливість статі та пов'язані 3 нею гендерні стереотипи є концепція соціального конструювання реальності П. Бергера i Т. Лукмана, теорія соціального конструювання Т. Парсонса, теорія соціалізації Т. Парсонса і Р. Бейлза, теорія драматургійного інтеракціонізму I. Гоффмана.

Соціально-конструктивістський підхід щодо гендерних стереотипів, стверджують провідні науковці (Т. Власова, О. Вороніна, І. Кльоцина, С. Оксамитна та ін.), заснований на переконанні, що соціальні образи жінки та чоловіка створюються самим суспільством, $є$ продуктом його культурного розвитку, а тому не зумовлені біологічною даністю людини. Унаслідок цього не існує «жіночого» та «чоловічого» як природного та незмінного, а соціальні уявлення про них формуються протягом тривалої, пролонгованої, постійно відтворюваної взаємодії між статями згідно з суспільними традиціями.

Здійснений аналіз наукової літератури [3, с. 8; 5, с. 98-99], дозволяє визначати, передусім, негативні функції гендерних стереотипів у межах сім'ї: емоційно-оцінювальну, афективну (поділ людей на «своїх» і «чужих»), функцію захисту норм, функцію суворого контролю за дотриманням суспільних вимог. Теоретики соціального конструювання гендеру переконливо доводять, що саме такі деструктивні вияви гендерних стереотипів спричиняють статеворольові очікування членів родини одне до одного як представників протилежної статі.

На разі, спираючись на вихідні концептуальні положення соціально-конструктивістського підходу, розглянемо особливості функціонування гендерних стереотипів на рівні визначених нами компонентів сімейного виховання: «батьки - процес сімейного виховання - діти». При цьому спробуємо порушити питання про безумовно деструктивні функції таких стереотипів у контексті проблем сімейного виховання.

Провідні гендерологи зауважують, що саме батьки є основними носіями і трансляторами гендерних стереотипів у сімейному колі. Будучи вже сформованими особистостями, батько й мати продовжують знаходити підтвердження й схвалення своїх маскулінних або фемінних рис характеру та відповідних моделей поведінки серед колег, мікросоціуму, у ЗМІ. У відповідь на це вони й надалі формують розуміння того, що їхній гендер (соціальна стать) є постійним й змінити його не можна, стимулюють розвиток і закріплення відповідних переконань у дітей, а також вибудовують свої взаємовідносини з ними відповідно до їхньої біологічної статі. 
На підтвердження стереотипного бачення виховання дітей протилежної статі наведемо деякі дані досліджень Дж. Х. Блок [2, с. 169-171], В. Єремєєвої й Т. Хризман [цит. за 6, с. 278280], О. Кікінежді [7, с. 10-11], Н. Чодороу [12, с. 29-76] та ін. Згідно з результатами їхніх розвідок жінки більше контролюють поведінку доньок, натомість синам дозволяють виявляти агресію. Чоловіки-батьки схильні перш за все контролювати поведінку дітей власної статі. По відношенню до дівчат вони схвалюють їхню залежність від інших, від синів вимагають вияву фізичної сили, енергії, імпровізації. Батьки конструюють риси характеру й моделі поведінки дітей за допомогою конкретних маніпуляцій, вербальних апеляцій, каналізації (спрямування уваги дитини на певний об'єкт), демонстрації діяльності («дівчата, як мами, хлопчики, як батьки»). Уважаємо, за таких умов гендерні стереотипи заважають батькам бачити і сприймати своїх дітей такими, якими вони є, незалежно від їхньої статевої приналежності.

Стереотипне ставлення батьків до статі дітей багато в чому визначає й складники процесу сімейного виховання - мету, зміст, принципи, методи і засоби. Мета виховання (для чого виховуємо?) дівчат i хлопчиків у родині зазвичай детермінована соціокультурними експектаціями щодо призначення чоловічої статі - бути лідером, керівником, і жіночої - бути домогосподаркою, «берегинею домашнього вогнища».

Принципи сімейного виховання (на основі чого виховуємо?) щодо хлопців грунтуються на авторитеті батька як сильнішого, антижіночності, усвідомленні того, що варто розраховувати лише на власні сили й досягнення; основа виховання дівчат - «ії добробут, самоповага залежить від того, як до неї ставляться інші люди».

Зміст виховної діяльності батьків (що виховуємо?) також традиційно є відмінним для хлопчиків - наполегливість, активність, упевненість у собі; для дівчат - емпатійність, поступливість, дбайливість, чуттєвість тощо.

Методи і засоби (за допомогою чого виховуємо?), які пропонують і застосовують батьки щодо хлопчиків і дівчат $є$ однаковими, але їхнє функціональне значення зазвичай відмінне 3 огляду на стать дітей і батьків. Більшість виховних засобів допомагає дітям практикуватися у тих видах діяльності, які вважаються «природніми» 3 огляду на їхню стать. Так, предмети матеріальної і духовної культури спрямовують дівчат на підготовку до материнства, ведення домашнього господарства, оволодіння навичками обслуговування, хлопців - на більш творчі, лідерські заняття, пов'язані з ініціативою, у деяких випадках агресією [7, с. 11].

Можемо констатувати, що складники процесу сімейного виховання також детерміновані гендерними стереотипами, а тому відіграють роль нормативного тиску під час формування соціальної статі дітей, пов'язаних із нею життєвих орієнтирів і переконань.

Перейдемо до розгляду останнього складника сімейного виховання - дітей. За даними сучасних дослідників (І. Вихор, Т. Дороніної, В. Кравця та ін.), хлопчики і дівчата можуть як свідомо, так і на підсвідомому рівні засвоювати й відтворювати гендерні стереотипи. Так, стаючи об'єктом соціального конструювання своєї соціальної статі, діти приймають і розвивають цінності, установки, риси поведінки, персональні характеристики, які батьки прищеплюють їм (подекуди жорстко нав'язують) у процесі сімейного виховання. Підтвердження цього знаходимо в теоретиків соціального конструювання П. Бергера і Т. Лукмана, які зазначають, що будь-які стереотипи формуються у процесі соціалізації під час засвоєння культурних цінностей, норм і уявлень про належну рольову поведінку особистості, а їхній зміст відповідає загальноприйнятим суспільним нормам. Цей процес відбувається протягом первинної соціалізації. У подальшому (у період вторинної соціалізації) індивід у своїй свідомості й поведінці відтворює такі стереотипи, тобто певні, створені й легітимізовані суспільством уявлення про належні риси характеру та пов'язані з ними соціальні ролі [1, с. 212-215].

Саме в такий спосіб діти у процесі свого розвитку й формування в родині на підсвідомому рівні, автоматично приймають і відтворюють «свою» соціальну стать, пов'язані з нею гендерні стереотипи, ролі. При цьому, наголошуе Т. Рябова $[11$, с. 8$]$, діти не лише отримують інформацію про зміст понять «маскулінне» і «фемінне», але й постійно знаходять підтвердження цієї інформації у власному і батьківському життєвих досвідах.

У результаті діти, досягнувши рівня гендерної ідентичності (сприйняття себе як представника певної статі [8, с. 7]), самі детермінують гендерні ролі та ідеали, що існують у суспільстві, стають носіями гендерних стереотипів, агентами їхньої передачі в межах дитячої субкультури. За таких умов уповільнюється формування в дітей адекватних світоглядних 
позиції щодо пріоритету розвитку індивідуальних якостей і здібностей, унеможливлюється утвердження принципу взаємодоповнюваності й партнерства статей.

Вище наведене дозволяє сформулювати певні висновки. Залучення категорії гендеру в дослідження проблем сімейного виховання має значний теоретико-методологічний потенціал. Унаслідок цього стає можливим адекватне визначення упереджень щодо виховання статі дітей, які виникають на основі існуючих у суспільстві гендерних стереотипів.

3'ясовано, що гендерні стереотипи - це стійкі, стандартизовані соціокультурні утворення, які визначають традиційні моделі поведінки та риси характеру, які відповідають поняттям «чоловіче» і «жіноче». У багатьох сучасних сім'ях, які характеризуються патріархальним укладом життя, такі стереотипи продовжують прищеплюватися дітям обох статей.

Наголошено, гендерні стереотипи призводять до гендерної нерівності та дискримінації за ознакою статі в сучасній родині. На нашу думку, розв'язання такого роду утруднень вимагає нагальної зміни установок батьків і дітей щодо статі, переконструювання поведінки, зовнішніх маркерів та внутрішніх якостей осіб чоловічої та жіночої статі згідно з їхніми природними нахилами і задатками. Дослідження гендерних стереотипів актуальне допоки в суспільстві не будуть здоланими традиційні погляди на природу, ролі та якості чоловіків та жінок, взаємовідносини між ними, сімейне виховання дітей за їхньою статтю.

У подальшому визначаємо потребу дослідити природу, механізми відтворення, причини подальшої трансляції гендерних стереотипів на рівні складників сімейного виховання в руслі теорії соціального конструювання статі задля зменшення їх деструктивного впливу й гармонізації взаємин статей.

\section{1. Бергер II. Социальное конструированература}

1. Бергер П. Социальное конструирование реальности. Трактат по социологии знания / Питер Бергер, Томас Лукман. - М. : Медиум, 1995. - 323 с. 2. Блок Х. Дж. Влияние дифференцированной социализации на развитие личности мужчин и женщин / Джин Х. Блок // Практикум по социальной психологии : [сост. Э. Пайнс, К. Маслач]. - СПб. : Питер, 2000. - С. 168-181. 3. Вілкова О. Ю. Конструктивні та деструктивні функції гендерних стереотипів : автореф. на здобуття наук. ступеня канд. соціол. наук : спец. 22.00 .04 «Спеціальні та галузеві соціології» / О. Ю. Вілкова. - К., 2005. - 18 с. 4. Власова Т. І. Формування гендерних стереотипів у західноєвропейській філософії (історикофілософський аналіз) : автореф. на здобуття наук. ступеня докт. філос. наук : спец. 09.00.05 «Історія філософії» / Т. І. Власова. - Дніпропетровськ, 2007. - 37 с. 5. Дороніна Т. О. Теоретико-методологічні засади гендерної освіти та виховання учнівської молоді : [монографія] / Т. О. Дороніна. - Кривий Ріг : Видавничий дім, 2011. - 331 с. 6. Ильин Е. П. Особенности воспитания в семье мальчиков и девочек родителями разного пола / Е. П. Ильин // Дифференциальная психология мужчин и женщин. - СПб. : Питер, 2003. - С. 274-280. 7. Кікінежді О. Гендерне виховання змалку / О. Кікінежді //Дошкільне виховання. - 2006. - № 3. - С. 10-13. 8. Клёцина И. С. Гендерная социализация : [учеб. пособ.]/ И. С. Клёцина. - СПб. : Издательство РГПУ им. А. И. Герцена, 1998. - 92 с. 9. Кутова Н. А. Вища освіта жінок у США в 70-х роках XX - на початку XXI ст.: гендерний підхід / Н. А. Кутова. - К. : ПУЛЬСАРИ, 2008. - 312 с. 10. Луценко О. А. Гендерна освіта й педагогіка / О. А. Луценко // Основи теорії гендеру: [навч. посіб.]. - К. : «К.І.С.», 2004. - С. 476-503. 11. Рябова Т. Б. Гендерные стереотипы и гендерная стереотипизация: методологические проблемы / Т. Б. Рябова // Женщина в Российском обществе. - 2001 - № 3-4. - С. 3-12. 12. Чодороу Н. Воспроизводство материнства: психоанализ и социология пола / Нэнси Чодороу; [пер. с англ.] // Антология гендерной теории: [сост. Е. И. Гапова, А. Р. Усманова]. - Минск : Пропилеи, 2000. - С. 29-76.

УДК 372.851

Наталя Рашевська

\section{ВИКОРИСТАННЯ ІННОВАЦІЙНИХ ТЕХНОЛОГІЙ У ПРОЦЕСІ НАВЧАННЯ ВИЩОЇ МАТЕМАТИКИ}

Рашевська Н. В. Використання інноваційних технологій у процесі навчання вищої математики.

У статті розглянуто деякі форми організації процесу навчання вищої математики за моделлю змішаного навчання 3 використанням мобільних інформаційно-комунікаційних технологій. Визначено принципи організації навчання вищої математики засобами мобільних ІКТ.

Ключові слова: мобільні інформаційно-комунікаційні технології, змішане навчання, відеолекція, мультимедіалекція, комп’ютерно-орієнтовані практичні заняття. 